\title{
Clinical Relevance of Blood Glucose Concentration and Hyperglycemia Management in Neurocritical Care Patients
}

\author{
Federico Bilotta ${ }^{1}$ Ega Qeva ${ }^{1} \quad$ Anna Prete $^{1} \quad$ Francesco Pugliese $^{1}$ \\ ${ }^{1}$ Department of Anaesthesia and Critical Care Medicine, Policlinico \\ Umberto I Hospital, Sapienza University of Rome, Rome, Italy \\ Address for correspondence Federico Bilotta, MD, PhD, \\ Department of Anesthesiology and Critical Care, University of Rome \\ "La Sapienza", Policlicnico Umberto I Hospital, Via Acherusio 16, \\ Rome, 00199 Italy (e-mail: bilotta@tiscali.it).
}
Abstract
Keywords
- acute brain injury
- blood glucose concentration
- insulin infusion therapy
- neurocritical care

In patients admitted to a neurocritical care (NCC) unit, management of blood glucose concentration (BGC) is a challenging clinical task. Several studies have shown that episodes of hypo- and hyperglycemia and high BGC variability are associated with poor short- and long-term outcomes. Optimal BGC target-range and BGC management in NCC patients have dramatically evolved in the past decades and new insulin infusion and adequate nutrition protocols are now available. The aim of this narrative review is to report the state-of-the-art on clinical relevance on BGC and hyperglycemia management in NCC patients.

\section{Introduction}

In patients with acute brain injury (ABI) admitted to neurocritical care (NCC), the management of blood glucose concentration (BGC) is a controversial topic and a challenging clinical task..$^{1-4}$ It is well established that hypoglycemia-defined as BGC $<80 \mathrm{mg} / \mathrm{dL}-$ is a risk factor for cerebral dysfunction. ${ }^{1}$ Hypoglycemia exerts its effects on the central nervous system through three mechanisms: induction of a systemic stress response (increased sympathetic tone), increase in cerebral blood flow, and modification of cerebral energy metabolism by use of nonglucose substrates (pyruvate, glycogen, ketone bodies, glutamate, glutamine, and aspartate). ${ }^{2}$ More recently, also hyperglycemia and high BGC variability have been shown to predict adverse outcomes in patients with $\mathrm{ABI}$ due to various causes: traumatic brain injury (TBI), acute ischemic stroke (AIS), intracranial hemorrhage (ICH), subarachnoid hemorrhage (SAH), etc. ${ }^{1,3}$ Hyperglycemia in ABI is exacerbated primarily through the activation of the hypothalamo-hypophyseal-adrenal axis, consecutively by elevated cortisol secretion and induction of gluconeogenesis. ${ }^{4}$

Optimal BGC target-range and BGC management in NCC patients have dramatically evolved in the past decades

received

February 2, 2019

accepted after revision

April 9, 2019

published online

June 7, 2019 and new information on insulin infusion therapy and the relevance of adequate nutrition protocol are now available.,

A literature search of PubMed online medical database and EMBASE online medical database was performed in December 2018 using the following keywords: blood glucose concentration, acute brain injury, and insulin infusion therapy. A total of 256,452 results were obtained, and after screening and assessing the titles, abstracts, and full-texts, 38 manuscripts were retrieved.

In this narrative review, we report the state-of-the-art on clinical relevance on BGC and hyperglycemia management in NCC patients.

\section{Clinical Relevance of BGC in NCC Patients}

In this section, evidence related to the predictive value of BGC abnormalities at admission (BGC within the first $24 \mathrm{~h}$ ) and during NCC stay, including hypo- and hyperglycemia and high glucose variability, will be presented (- Tables $\mathbf{1}$ and $\mathbf{2}$ ).

Predictive Value of BGC Abnormalities at NCC Admission In patients admitted to NCC with mixed ABI diagnosis, both hyper- and hypoglycemia at admission predict mortality and neurological functional outcome. ${ }^{6-17}$

Copyright @2019 Indian Society of Neuroanaesthesiology and Critical Care
License terms

(2) (1) $\Theta \circledast$ 10.1055/s-0039-1689069

ISSN 2348-0548. 
Table 1 Predictive value of BGC abnormalities at NCC admission

\begin{tabular}{|c|c|c|c|c|c|c|c|}
\hline Authors & $\begin{array}{l}\text { Year of } \\
\text { publication }\end{array}$ & $\begin{array}{l}\text { Type of } \\
\text { study }\end{array}$ & $\begin{array}{l}\text { Number of } \\
\text { patients }\end{array}$ & $\begin{array}{l}\text { ICU/NCC } \\
\text { patients }\end{array}$ & Objective of the study & Outcome(s) & $p$-Value \\
\hline $\begin{array}{l}\text { Walia and } \\
\text { Sutcliffe }\end{array}$ & 2002 & $\begin{array}{l}\text { Retro- } \\
\text { spective } \\
\text { study }\end{array}$ & 338 & NCC & $\begin{array}{l}\text { Hyperglycemia in the first } \\
24 \mathrm{~h} \text { and outcome in se- } \\
\text { verely head injured adults }\end{array}$ & $\begin{array}{l}\text { Mortality increases linearly as } \\
\text { blood glucose increase }\end{array}$ & $<0.0001$ \\
\hline $\begin{array}{l}\text { Liu-DeRyke } \\
\text { et } \mathrm{al}^{7}\end{array}$ & 2009 & $\begin{array}{l}\text { Retro- } \\
\text { spective } \\
\text { study }\end{array}$ & 380 & NCC & $\begin{array}{l}\text { BGC at admission and } \\
\text { mortality and poor } \\
\text { outcomes in TBI }\end{array}$ & $\begin{array}{l}\text { Higher BGC (> } 160 \mathrm{mg} / \mathrm{dL} \text { ) at } \\
\text { admission and during the first } 24 \mathrm{~h} \\
\text { of admission had higher mortality } \\
\text { and poor outcome irrespective of } \\
\text { severity of injury }\end{array}$ & $<0.001$ \\
\hline Melo et $\mathrm{al}^{8}$ & 2010 & $\begin{array}{l}\text { Retro- } \\
\text { spective } \\
\text { study }\end{array}$ & 286 & NCC & $\begin{array}{l}\text { High BGC at admission and } \\
\text { in the first } 48 \mathrm{~h} \text { and out- } \\
\text { come measured with GOS } \\
\text { in children with severe TBI } \\
\text { at hospital discharge and } 6 \\
\text { months later }\end{array}$ & $\begin{array}{l}\text { High BCG at admission is asso- } \\
\text { ciated with mortality and bad } \\
\text { outcome }\end{array}$ & $<0.001$ \\
\hline $\begin{array}{l}\text { Bhattacha- } \\
\text { rjee et } \text { al }^{9}\end{array}$ & 2014 & $\begin{array}{l}\text { Pro- } \\
\text { spective } \\
\text { study }\end{array}$ & 200 & NCC & $\begin{array}{l}\text { Relationship between in- } \\
\text { traoperative blood glucose } \\
\text { variability in nondiabetic } \\
\text { patients and severity, } \\
\text { type of brain trauma, and } \\
\text { patients' demographic } \\
\text { variables }\end{array}$ & $\begin{array}{l}\text { Independent predictors of intraop- } \\
\text { erative hyperglycemia are severe } \\
\text { head injury }(G C S<9) \text { and acute } \\
\text { subdural hemorrhage }\end{array}$ & $\begin{array}{l}=0.001 \\
\text { (severity) } \\
=0.005 \\
\text { (type of } \\
\text { trauma) }\end{array}$ \\
\hline $\begin{array}{l}\text { Bosarge } \\
\text { et al }{ }^{10}\end{array}$ & 2015 & $\begin{array}{l}\text { Retro- } \\
\text { spective } \\
\text { study }\end{array}$ & 626 & NCC & $\begin{array}{l}\text { Stress-induced hyperglyce- } \\
\text { mia vs. diabetic hyper- } \\
\text { glycemia in severe TBI } \\
\text { patients }\end{array}$ & $\begin{array}{l}\text { Patients with stress-induced } \\
\text { hyperglycemia have higher mortal- } \\
\text { ity rate than diabetic hyperglyce- } \\
\text { mia patients }\end{array}$ & $<0.04$ \\
\hline Rau et al ${ }^{11}$ & 2017 & $\begin{array}{l}\text { Retro- } \\
\text { spective } \\
\text { study }\end{array}$ & 1798 & NCC & $\begin{array}{l}\text { Stress-induced hyperglyce- } \\
\text { mia vs. diabetic hyper- } \\
\text { glycemia in severe TBI } \\
\text { patients }\end{array}$ & $\begin{array}{l}\text { Stress-induced hyperglycemia } \\
\text { patients have } 6.6 \text {-fold higher odds } \\
\text { of mortality compared to diabetic } \\
\text { hyperglycemia patients }\end{array}$ & $<0.001$ \\
\hline $\begin{array}{l}\text { Salehpour } \\
\text { et al }{ }^{12}\end{array}$ & 2016 & $\begin{array}{l}\text { Pro- } \\
\text { spective } \\
\text { study }\end{array}$ & 80 & NCC & $\begin{array}{l}\text { Relationship between } \\
\text { serum BGC at admis- } \\
\text { sion and outcome in TBI } \\
\text { patients }\end{array}$ & $\begin{array}{l}\text { No differences reported in terms } \\
\text { of mortality rate, GCS, BGC at } \\
\text { discharge }\end{array}$ & $>0.05$ \\
\hline Lee et $\mathrm{al}^{13}$ & 2010 & $\begin{array}{l}\text { Pro- } \\
\text { spective } \\
\text { study }\end{array}$ & 1387 & NCC & $\begin{array}{l}\text { Relationship between BGC } \\
\text { at admission and mortality } \\
\text { in ICH patients }\end{array}$ & $\begin{array}{l}\text { High admission BGC was asso- } \\
\text { ciated with early and long-term } \\
\text { mortality }\end{array}$ & $<0,001$ \\
\hline Wu et al ${ }^{14}$ & 2012 & $\begin{array}{l}\text { Retro- } \\
\text { spective } \\
\text { study }\end{array}$ & 62 & NCC & $\begin{array}{l}\text { BGC at admission and } \\
\text { outcome after discharge } \\
\text { in patients with acute } \\
\text { cerebellar hemorrhage }\end{array}$ & $\begin{array}{l}\text { BGC }>140 \mathrm{mg} / \mathrm{dL} \text { on arrival is an } \\
\text { independent risk factor for poor } \\
\text { outcome }\end{array}$ & $=0.008$ \\
\hline $\begin{array}{l}\text { Appel- } \\
\text { boom } \\
\text { et al }{ }^{15}\end{array}$ & 2011 & \begin{tabular}{l|} 
Pro- \\
spective \\
study
\end{tabular} & 104 & NCC & $\begin{array}{l}\text { Relationship between BGC } \\
\text { at admission and clinical } \\
\text { and radiographic parame- } \\
\text { ters in ICH patients }\end{array}$ & $\begin{array}{l}\text { Admission hyperglycemia is } \\
\text { associated with poor outcome and } \\
\text { the presence of intraventricular } \\
\text { extension }\end{array}$ & $<0.04$ \\
\hline Sun et al ${ }^{16}$ & 2016 & $\begin{array}{l}\text { Pro- } \\
\text { spective } \\
\text { study }\end{array}$ & 2951 & NCC & $\begin{array}{l}\text { Relationship between } \\
\text { admission BGC and clinical } \\
\text { outcomes in diabetic and } \\
\text { nondiabetic patients with } \\
\text { ICH }\end{array}$ & $\begin{array}{l}\text { Elevated admission BGC confers } \\
\text { a higher risk of poor outcome at } \\
3 \text { months in nondiabetics than } \\
\text { diabetics with similar glucose level } \\
\text { with ICH }\end{array}$ & $<0.002$ \\
\hline Kim et al. ${ }^{17}$ & 2016 & $\begin{array}{l}\text { Retro- } \\
\text { spective } \\
\text { study }\end{array}$ & 538 & NCC & $\begin{array}{l}\text { Relationship between BGC } \\
\text { at admission and 3-month } \\
\text { mortality in patients with } \\
\text { spontaneous supratentorial } \\
\text { ICH }\end{array}$ & $\begin{array}{l}\text { Admission } \mathrm{BGC}>134 \mathrm{mg} / \mathrm{dL} \text { is } \\
\text { associated with higher } 3 \text {-month } \\
\text { mortality }\end{array}$ & $=0.001$ \\
\hline
\end{tabular}

Abbreviations: BGC, blood glucose concentration; GCS, Glasgow coma scale; GOS, Glasgow outcome score; ICH, intracranial hemorrhage; NCC, neurocritical care; TBI, traumatic brain injury. 
Table 2 Predictive value of BGC abnormalities during ICU/NCC stay

\begin{tabular}{|c|c|c|c|c|c|c|c|}
\hline Authors & $\begin{array}{l}\text { Year of } \\
\text { publi- } \\
\text { cation }\end{array}$ & Type of study & $\begin{array}{l}\text { Num- } \\
\text { ber of } \\
\text { patients }\end{array}$ & $\begin{array}{l}\text { ICU/ } \\
\text { NCC } \\
\text { pa- } \\
\text { tients }\end{array}$ & Objective of the study & Outcome(s) & $p$-Value \\
\hline Elkon et al ${ }^{18}$ & 2014 & $\begin{array}{l}\text { Retrospective } \\
\text { study }\end{array}$ & 271 & NCC & $\begin{array}{l}\text { Relationship between high } \\
\text { BGC and poor outcome in } \\
\text { pediatric TBI }\end{array}$ & $\begin{array}{l}\text { Severe hyperglycemic } \\
\text { patients had a poorer } \\
\text { outcome compared with } \\
\text { the mild hyperglycemia } \\
\text { group }\end{array}$ & $>0.05$ \\
\hline Bian et al ${ }^{19}$ & 2013 & $\begin{array}{l}\text { Prospective } \\
\text { study }\end{array}$ & 239 & NCC & $\begin{array}{l}\text { Relationship between fasting } \\
\text { glucose level on admission, } \\
\text { day } 14 \text { or their variation and } \\
1 \text {-year mortality in patients } \\
\text { with aSAH }\end{array}$ & $\begin{array}{l}\text { Fasting glucose level on } \\
\text { admission day } 14 \text { or their } \\
\text { variation are independent } \\
\text { risk factors for death at } \\
1 \text { year }\end{array}$ & $<0.01$ \\
\hline Koga et a ${ }^{20}$ & 2015 & $\begin{array}{l}\text { Prospective } \\
\text { study }\end{array}$ & 176 & NCC & $\begin{array}{l}\text { Relationship between BGC } \\
\text { at admission and during the } \\
\text { initial } 72 \text { h after acute ICH } \\
\text { and outcomes in terms of } \\
\text { hematoma expansion and } \\
\text { disability (measured with } \\
\text { modified Rankin scale) }\end{array}$ & $\begin{array}{l}\text { High blood glucose levels } \\
\text { at admission and } 72 \\
\text { h were independently } \\
\text { associated with higher } \\
\text { disability at 3-month } \\
\text { follow-up, but not with } \\
\text { hematoma expansion }\end{array}$ & $<0.01$ \\
\hline $\begin{array}{l}\text { Sugiura } \\
\text { et } \mathrm{al}^{21}\end{array}$ & 2016 & $\begin{array}{l}\text { Prospective } \\
\text { study }\end{array}$ & 204 & NCC & $\begin{array}{l}\text { Clarify the predictors of } \\
\text { symptomatic intracranial } \\
\text { hemorrhage after endovascu- } \\
\text { lar treatment in patients with } \\
\text { acute AIS }\end{array}$ & $\begin{array}{l}\text { Patients with mild } \\
\text { hyperglycemia had } \\
\text { extremely higher risk of } \\
\text { symptomatic intracranial } \\
\text { hemorrhage compared to } \\
\text { patients with normal BGC }\end{array}$ & $<0.04$ \\
\hline Egi et $a^{22}$ & 2010 & $\begin{array}{l}\text { Retrospective } \\
\text { study }\end{array}$ & 4,946 & ICU & $\begin{array}{l}\text { Relationship between } \\
\text { moderate hypoglycemia and } \\
\text { increased risk of death in ICU } \\
\text { patients }\end{array}$ & $\begin{array}{l}\text { Higher mortality in } \\
\text { patients with moderate } \\
\text { hypoglycemia }\end{array}$ & $<0.001$ \\
\hline $\begin{array}{l}\text { Krinsley } \\
\text { et } \mathrm{al}^{23}\end{array}$ & 2011 & $\begin{array}{l}\text { Retrospective } \\
\text { study }\end{array}$ & 6,240 & ICU & $\begin{array}{l}\text { Relationship between hypo- } \\
\text { glycemia (BGC < } 70 \mathrm{mg} / \mathrm{dL} \text { ) } \\
\text { and ICU-LOS }\end{array}$ & $\begin{array}{l}\text { Patients with hypoglyce- } \\
\text { mia had longer ICU LOS }\end{array}$ & $<0.0001$ \\
\hline $\begin{array}{l}\text { Naidech } \\
\text { et } \mathrm{al}^{24}\end{array}$ & 2009 & $\begin{array}{l}\text { Prospective } \\
\text { study }\end{array}$ & 172 & NCC & $\begin{array}{l}\text { Hypoglycemia and neurologic } \\
\text { outcomes in patients with } \\
\text { SAH }\end{array}$ & $\begin{array}{l}\text { Progressive reductions of } \\
\text { BGC }(<80 \mathrm{mg} / \mathrm{dL}) \text { are as- } \\
\text { sociated with increasing } \\
\text { functional disability at } 3 \\
\text { months after SAH }\end{array}$ & $<0.001$ \\
\hline $\begin{array}{l}\text { Graffagnino } \\
\text { et al }{ }^{25}\end{array}$ & 2010 & $\begin{array}{l}\text { Retrospective } \\
\text { study }\end{array}$ & 3,709 & ICU & $\begin{array}{l}\text { Relationship between IIT and } \\
\text { short-term outcome }\end{array}$ & $\begin{array}{l}\text { The likelihood of mor- } \\
\text { tality increased propor- } \\
\text { tionally as the severity of } \\
\text { hypoglycemia worsened }\end{array}$ & $<0.04$ \\
\hline $\begin{array}{l}\text { Hermanides } \\
\text { et al }\end{array}$ & 2010 & $\begin{array}{l}\text { Retrospective } \\
\text { study }\end{array}$ & 5,728 & ICU & $\begin{array}{l}\text { Glucose variability in ICU } \\
\text { population and mortality }\end{array}$ & $\begin{array}{l}\text { Patients with higher } \\
\text { mean glucose variability } \\
\text { per hour have higher } \\
\text { incidence of death }\end{array}$ & $<0.001$ \\
\hline $\begin{array}{l}\text { Matsushima } \\
\text { et } \mathrm{al}^{27}\end{array}$ & 2012 & $\begin{array}{l}\text { Retrospective } \\
\text { study }\end{array}$ & 109 & NCC & $\begin{array}{l}\text { Impact of glucose variability } \\
\text { on long-term functional out- } \\
\text { come of patients with TBI }\end{array}$ & $\begin{array}{l}\text { Glucose variability is } \\
\text { associated with lower } \\
\text { GOSE score }\end{array}$ & $<0.04$ \\
\hline $\begin{array}{l}\text { Okazaki } \\
\text { et } \mathrm{al}^{28}\end{array}$ & 2016 & $\begin{array}{l}\text { Retrospective } \\
\text { study }\end{array}$ & 122 & NCC & $\begin{array}{l}\text { Increased glucose variability } \\
\text { and neurological outcome in } \\
\text { patients with aSAH }\end{array}$ & $\begin{array}{l}\text { Glucose variability is } \\
\text { associated with worse } \\
\text { neurological outcome }\end{array}$ & $<0.04$ \\
\hline
\end{tabular}

Abbreviations: aSAH, acute subarachnoid hemorrhage; BGC, blood glucose concentration; GOSE, extended Glasgow outcome score; $\mathrm{ICH}$, intracranial hemorrhage; ICU, intensive care unit; IIT, intensive insulin therapy; LOS, length of stay; NCC, neurocritical care; TBI, traumatic brain injury.

In a retrospective study including 338 severe brain injured patients, severe hyperglycemia (BGC $>180 \mathrm{mg} / \mathrm{dL}$ ) was associated with increased morbidity (risk of brain edema, reduction in cerebral perfusion, inflammatory reaction) and mortality. ${ }^{6}$ In patients with TBI, severe and mild hyperglycemia predicts increased mortality and worse neurological outcome. In a retrospective observational study, data from 380 adult TBI patients were reviewed and demonstrated 
that mild hyperglycemia (BGC $>160 \mathrm{mg} / \mathrm{dL}$ ) was associated with a higher mortality. ${ }^{7}$ Also in pediatric TBI patients, severe hyperglycemia (BGC > $200 \mathrm{mg} / \mathrm{dL}$ ) at admission and in the first 48 hours after arrival to NCC was associated with increased mortality and worse neurological outcome (Glasgow outcome scale [GOS] at discharge and at 6 months) as reported in data from a retrospective study in 286 children with severe TBI (Glasgow coma scale $\left[\right.$ GCS] $<8$ ). ${ }^{8}$ In patients with TBI, hyperglycemia-induced "secondary brain damage" is caused by multiple mechanisms and involves the increased lactate/pyruvate ratio that results in cerebral metabolic acidosis and ultimately neuronal cell death. ${ }^{9}$ In patients with TBI, increased mortality associated with hyperglycemia seems to correlate more with stress-induced hyperglycemia rather than with diabetic hyperglycemia. In a retrospective study, data analysis from 626 patients with severe TBI showed that admission hyperglycemia, with BGC > $200 \mathrm{mg} /$ $\mathrm{dL}$, was associated with increased mortality in patients with stress-induced hyperglycemia more than that in nondiabetic normoglycemic patients; while there was no difference in mortality between nondiabetic normoglycemic and diabetic hyperglycemia patients. ${ }^{10}$ This result was confirmed by a retrospective study in 1,798 patients with moderate-tosevere TBI that showed a 6.6-fold higher mortality in severe stress-induced hyperglycemia (BGC > $200 \mathrm{mg} / \mathrm{dL}$ ) than in severe diabetic hyperglycemia. ${ }^{11}$ Evidence on hyperglycemia-associated worse outcome in TBI patients was partly challenged by a prospective study that included 80 patients with severe TBI (GCS $<8$ at admission) and reported no differences in functional outcome at hospital discharge (measured by GOS) between patients presenting normal or high BGC. ${ }^{12}$ The relatively limited number of recruited patients, the heterogeneity of clinical conditions at NCC admission, and the short follow-up might have prevented to detect differences between the groups. In patients with TBI, also severe hypoglycemia (BGC $<60 \mathrm{mg} / \mathrm{dL}$ ) has been proven to predict higher mortality. In a retrospective observational study, data from 380 TBI patients were reviewed and demonstrated that severe hypoglycemia-when detected within the first $24 \mathrm{~h}$ after NCC admission-was associated with a higher mortality and worse clinical course in terms of longer mechanical ventilation and intensive care unit (ICU) and hospital stay. ${ }^{7}$

Also, in patients with $\mathrm{ICH}$, severe and mild hyperglycemia at NCC admission is associated with higher mortality and worse functional outcome. A prospective study that reported data from 1,387 patients with ICH demonstrated that mild hyperglycemia (BGC $>160 \mathrm{mg} / \mathrm{dL}$ ) at NCC admission was an overall independent predictor of early mortality at 30 days of follow-up. ${ }^{13}$ In the same study, the analysis of the clinical course in nondiabetic hyperglycemic patients showed a BGC-dependent increase in long-term mortality. ${ }^{13}$ This evidence was confirmed in 62 patients with ICH in whom mild hyperglycemia (BGC >140 mg/dL) at NCC arrival independently predicted increased mortality and worse neurological outcome. ${ }^{14}$ Also in 104 patients with $\mathrm{ICH}$, severe hyperglycemia $(\mathrm{BGC}>180 \mathrm{mg} / \mathrm{dL}$ ) at admission independently predicted higher mortality and worse functional outcome at 3 months, and correlated with severity of intraventricular hemorrhage. ${ }^{15}$ In 2,951 patients with ICH, mild hyperglycemia (BGC >136 mg/dL) at NCC admission independently predicted 3 months mortality and worse neurological outcome evaluated by modified Rankin Scale functional status. In the same study, patients without a previous history of diabetes had a higher risk of mortality and poor outcome when compared with diabetic patients. ${ }^{16}$ More recently, the relevance of BGC $>136 \mathrm{mg} / \mathrm{dL}$ at NCC admission in patients with ICH was further confirmed in a retrospective data analysis of 538 cases in whom the 3-month mortality increased in a dose-dependent manner (hazard ratio: 1.004; per $1 \mathrm{mg} / \mathrm{dL}$ increase). ${ }^{17}$

To conclude, the actual state-of-the-art evidence in literature supports that both hyperglycemia and hypoglycemia at NCC admission of adult and pediatric ABI patients (TBI, acute subarachnoid hemorrhage [aSAH], ICH, and AIS) correlate with higher morbidity (worse GOS, longer length of stay [LOS], etc.) and mortality.

Predictive Value of BGC Abnormalities during ICU/NCC Stay During NCC stay, patients with TBI, ICH, SAH, or AIS who present BGC abnormalities (hyperglycemia, hypoglycemia, and glucose variability) have worse clinical course. ${ }^{18-28}$

In 271 pediatric patients with moderate-to-severe TBI, severe hyperglycemia (BCG $>200 \mathrm{mg} / \mathrm{dL}$ ) was associated with poorer neurologic outcome than in those presenting mild hyperglycemia (BGC: $110-160 \mathrm{mg} / \mathrm{dL}$ ) and normal glycemia. ${ }^{18}$ Similarly, in patients with aSAH, ICH, and AIS, hyperglycemia was found to be a strong predictor of worse clinical course. A prospective study including 239 patients with aSAH evaluated the relationship between BGC at admission and BGC abnormalities during the first 14 days of NCC stay and correlation with 1-year mortality. ${ }^{19}$ In these patients, fasting glucose level at admission and extent of BGC abnormalities were independent risk factors for death at 1 year. In a prospective observational study that included 176 patients with $\mathrm{ICH}$, the relationship between severe hyperglycemia (BGC > $200 \mathrm{mg} / \mathrm{dL}$ ) at 24 hours and 72 hours and functional outcomes at 3 months (measured as death and disability) was studied and showed an inverse relationship between good functional status at follow-up and BGC values at 24 hours and 72 hours after admission and a positive relationship between BGC at 24 hours after admission and death. ${ }^{20}$ In 204 patients with AIS undergoing endovascular treatment, mild hyperglycemia (BGC $\geq 160 \mathrm{mg} / \mathrm{dL}$ ) independently predicted occurrence of symptomatic intracranial hemorrhage within 24 hours from symptoms onset when compared with normoglycemic patients. ${ }^{21}$

Hypoglycemia, in general ICU and in NCC patients (with $\mathrm{SAH}$, mixed $\mathrm{ABI}$ ), predicts increased mortality, poor neurological outcome, and longer LOS. In two retrospective observational studies that enrolled 4,946 and 6,240 general ICU patients, an episode of mild hypoglycemia (BGC < $82 \mathrm{mg} / \mathrm{dL}$ ) was independently associated with an increased risk of death and longer ICU-LOS than in patients who did not present hypoglycemia. ${ }^{22,23}$ Also in patients with SAH, as reported by a prospective study that included 172 patients, there was a relationship between mild hypoglycemia (BGC $<80 \mathrm{mg} / \mathrm{dL}$ ), the clinical course (intended as radiographic 
cerebral infarction and vasospasm), and functional neurological outcomes (measured through modified Rankin Scale at 14 days, 28 days, and 3 months). Patients with at least one episode of mild hypoglycemia had more radiographic cerebral infarction and symptomatic vasospasm and worse functional neurological status at 3 months follow-up. ${ }^{24}$ In 3,709 mixed neurological and neurosurgical patients admitted in NCC, there is a positive relationship between hypoglycemic episodes and mortality before as proven in a prospective study designed to evaluate the impact of intensive insulin therapy (IIT) protocol implementation. The severity of hypoglycemia was defined as moderate (BGC $<70 \mathrm{mg} / \mathrm{dL}$ ), severe (BGC $<40 \mathrm{mg} / \mathrm{dL}$ ), and extreme (BGC $<20 \mathrm{mg} / \mathrm{dL}$ ). The implementation of IIT protocol was associated with an increased incidence of hypoglycemic episodes. Furthermore, mortality increased proportionally with the severity of hypoglycemia.. ${ }^{25}$

High blood glucose variability in ICU/NCC patients correlates with mortality and with a worse neurological outcome in NCC patients affected with TBI and SAH. Data from a retrospective study including 5,728 ICU patients treated with a computerized insulin algorithm (target BGC 72-126 mg/ $\mathrm{dL}$ ) evaluated the relationship between glucose variability and ICU and in-hospital mortality. The glucose variability was calculated as mean absolute glucose change per hour and standard deviation. The highest mean absolute glucose change per hour was correlated with ICU mortality. ${ }^{26}$ Also in patients with TBI, as reported by a retrospective study including 109 patients, glucose variability predicts worse long-term functional outcome (Extended Glasgow Outcome Scale [GOSE] at a median of 6 months after injury). The glucose variability was calculated by standard deviation and percentage of excursion from the target BGC range. In these patients, higher mean BGC, percentage of excursion $>60 \%$, and single episode of BGC $<60 \mathrm{mg} / \mathrm{dL}$ correlated with a lower GOSE score. ${ }^{27}$ The predictive value of glucose variability was also confirmed in patients with SAH as reported by a retrospective study that included 122 patients. ${ }^{28}$ The glucose variability was an independent predictor of unfavorable neurological outcomes in patients who presented BGC values in the 80 to $139 \mathrm{mg} / \mathrm{dL}$ range. This predictive value was not confirmed in patients presenting BGC $>140 \mathrm{mg} / \mathrm{dL}$.

To conclude, the actual state-of-the-art evidence in literature supports that BGC abnormalities (hyperglycemia, hypoglycemia, and high glucose variability) in both adults and pediatric ICU/NCC patients correlate with higher morbidity (worse GOS and modified Rankin Scale, higher hematoma expansion, higher LOS, etc.) and mortality.

\section{Hyperglycemia Management in NCC}

In this section, evidence related to conventional or intensive glycemic control, optimal glycemic target range, and nutrition supply in general ICU and NCC patients will be presented ( - Tables 3 and 4 ).

\section{Conventional versus Intensive Glycemic Control and Optimal Glycemic Range}

In general ICU patients, IIT aimed to tight glycemic control is associated with lower morbidity and mortality and a higher rate of severe hypoglycemia. ${ }^{29,30}$ In 2001, a seminal randomized controlled trial (RCT) by Greet van den Berghe and her group enrolling 1,548 ICU patients, originally demonstrated that patients assigned to IIT, titrated to BGC between 80 and $110 \mathrm{mg} / \mathrm{dL}$, had lower mortality and morbidity (bloodstream infections, acute renal failure, red-cells transfusions, and polyneuropathy) than those assigned to conventional insulin therapy (CIT), in whom insulin was administered when BGC $>215 \mathrm{mg} / \mathrm{dL}$ to maintain BGC between 180 and $200 \mathrm{mg} / \mathrm{dL}^{29}$ This study was an irreversible step to reconsider the conventional approach to BGC management and insulin use in ICU patients, but had several controversial aspects and most important, only a fraction of enrolled patients suffered from ABI (63 patients). In 2009, a larger RCT-that enrolled 6,104 ICU patients-was conducted by NICE-SUGAR study investigators. ${ }^{30}$ Primary end point was comparison of 90-day mortality in patients receiving IIT (BGC, 81-108 mg/dL) or CIT (< $180 \mathrm{mg} / \mathrm{dL}$ ). In CIT group, insulin infusion was discontinued when BGC $<144 \mathrm{mg} / \mathrm{dL}$. Authors found that patients receiving IIT had a higher mortality rate and more severe hypoglycemic episodes (BGC $<40 \mathrm{mg} / \mathrm{dL}$ ) compared to patients treated with CIT. There was no difference in the median ICU-LOS or the median number of days of mechanical ventilation.

In general ICU patients, optimal BGC target range evolved: relationship between mortality and hypo/hyperglycemic episodes was described by a "U"-shaped curve; the lower the target range of $\mathrm{BGC}$, the higher was the risk to induce hypoglycemia. ${ }^{5,31,32,33}$ An editorial reported lower incidence of hyper/hypoglycemia and glucose variability for BGC target range between $140 \mathrm{mg} / \mathrm{dL}$ and $180 \mathrm{mg} / \mathrm{dL}$ in general ICU patients, whereas more recent evidence suggested that BGC target range between $129 \mathrm{mg} / \mathrm{dL}$ and $145 \mathrm{mg} / \mathrm{dL}$ was more effective, as it reduced the risk of hypoglycemia and hospital mortality rate. ${ }^{5,31}$ In trauma patients without TBI, BGC $<140$ $\mathrm{mg} / \mathrm{dL}$ reduced mortality. An RCT enrolling 2,038 general ICU patients divided them into three different BGC target range groups (group $\mathrm{H}<200 \mathrm{mg} / \mathrm{dL}$; group $\mathrm{M}<150 \mathrm{mg} / \mathrm{dL}$; group $\mathrm{L}<120 \mathrm{mg} / \mathrm{dL}$ ) and evaluated the incidence of hypoglycemia, morbidity and mortality. ${ }^{32}$ Group L had a higher incidence of moderate and severe hypoglycemia $(<60 \mathrm{mg} / \mathrm{dL} ;<40 \mathrm{mg} / \mathrm{dL}$ ). There were no differences among the groups in terms of morbidity and mortality. A retrospective study including general ICU patients reported that there was a "U"-shaped relationship between mortality and hypo/hyperglycemia during admission (BGC $<120$ and $>170 \mathrm{mg} / \mathrm{dL}$ respectively). ${ }^{33}$

In NCC patients, IIT aimed to tight glycemic control was associated with a higher risk of inducing hypoglycemia. ${ }^{3,34}$ The use of IIT has also been re-evaluated in NCC patients. ${ }^{3}$ An RCT conducted in severe TBI patients ( $G C S \leq 8$ ) assigned to receive IIT to maintain BGC between $80 \mathrm{mg} / \mathrm{dL}$ and $120 \mathrm{mg} / \mathrm{dL}$ or CIT to maintain BGC $<220 \mathrm{mg} / \mathrm{dL}$ showed that hypoglycemia incidence (BGC $<80 \mathrm{mg} / \mathrm{dL}$ ) was higher in the IIT group, ICU-LOS was shorter in the IIT group, whereas infection rate and mortality at 6 months were similar in the two groups. ${ }^{34}$ Another RCT conducted 1 year later, enrolled 483 NCC patients (ICH, neurovascular disease, tumor, and trauma) undergoing neurosurgery and compared the IIT approach titrated to BGC between $80 \mathrm{mg} / \mathrm{dL}$ and $110 \mathrm{mg} / \mathrm{dL}$ to the CIT 
Table 3 Conventional versus intensive glycemic control and optimal glycemic range

\begin{tabular}{|c|c|c|c|c|c|c|}
\hline Authors & $\begin{array}{l}\text { Year of } \\
\text { publication }\end{array}$ & $\begin{array}{l}\text { Type of } \\
\text { study }\end{array}$ & $\begin{array}{l}\text { ICU/NCC } \\
\text { patients }\end{array}$ & Objective of the study & Outcome(s) & $p$-Value \\
\hline $\begin{array}{l}\text { van den Berghe } \\
\text { et } a^{29}\end{array}$ & 2001 & $\mathrm{RCT}$ & $\mathrm{ICU}$ & $\begin{array}{l}\text { IIT (BGC } 80-110 \mathrm{mg} / \mathrm{dL}) \text { vs. } \\
\text { CIT (BGC } 180-200 \mathrm{mg} / \mathrm{dL}) \\
\text { in terms of mortality and } \\
\text { morbidity }\end{array}$ & $\begin{array}{l}\text { IIT group had lower } \\
\text { mortality and morbidity }\end{array}$ & $\leq 0.02$ \\
\hline $\begin{array}{l}\text { NICE-SUGAR } \\
\text { Study Investiga- } \\
\text { tors et al }{ }^{30}\end{array}$ & 2009 & $\mathrm{RCT}$ & $\mathrm{ICU}$ & $\begin{array}{l}\text { IIT }(\text { BGC } 81-108 \mathrm{mg} / \mathrm{dL}) \text { vs. } \\
\text { CIT (BGC } \leq 180 \mathrm{mg} / \mathrm{dL} \text { ) in } \\
\text { terms of mortality within } 90 \\
\text { days }\end{array}$ & $\begin{array}{l}\text { IIT group had higher } \\
\text { mortality rate }\end{array}$ & $=0.02$ \\
\hline Al-Tarifi et al ${ }^{31}$ & 2011 & $\mathrm{RCT}$ & $\mathrm{ICU}$ & $\begin{array}{l}\text { IIT (BGC } 80-110 \mathrm{mg} / \mathrm{dL} \text { ) vs. } \\
\text { CIT (BGC } 180-200 \mathrm{mg} / \mathrm{dL} \text { ) in } \\
\text { terms of mortality rate and } \\
\text { hypoglycemia incidence }\end{array}$ & $\begin{array}{l}\mathrm{BGC} \leq 146 \mathrm{mg} / \mathrm{dL} \\
\text { reduces mortality and } \\
\text { hypoglycemia incidence }\end{array}$ & $\begin{array}{l}\leq 0.02 \\
\text { (mortality) } \\
<0.0001 \\
\text { (hypoglycemia) }\end{array}$ \\
\hline Okawa et al ${ }^{32}$ & 2013 & $\mathrm{RCT}$ & $\mathrm{ICU}$ & $\begin{array}{l}\text { Three groups with different } \\
\text { target BGC: group } \mathrm{H}<200 \\
\mathrm{mg} / \mathrm{dL} ; \text { group } \mathrm{M}<150 \mathrm{mg} / \mathrm{dL} \text {; } \\
\text { group } \mathrm{L}<120 \mathrm{mg} / \mathrm{dL} \text { to eval- } \\
\text { uate incidence of hypoglyce- } \\
\text { mia, morbidity, and mortality }\end{array}$ & $\begin{array}{l}\text { Higher incidence of } \\
\text { moderate and severe } \\
\text { hypoglycemia in group } \\
\text { L; no differences in } \\
\text { morbidity and mortality } \\
\text { rate }\end{array}$ & $<0.01$ \\
\hline Siegelaar et a ${ }^{33}$ & 2010 & $\begin{array}{l}\text { Retro- } \\
\text { spec- } \\
\text { tive } \\
\text { study }\end{array}$ & $\mathrm{ICU}$ & $\begin{array}{l}\text { Effects of hypo/hyperglycemia } \\
\text { in admission on mortality rate }\end{array}$ & $\begin{array}{l}\text { "U"-shaped relationship } \\
\text { between hypo/hyper- } \\
\text { glycemia }(\mathrm{BGC}<120 \\
\mathrm{mg} / \mathrm{dL} \text { and }>170 \mathrm{mg} / \mathrm{dL}) \\
\text { and mortality rate }\end{array}$ & $\begin{array}{l}=0.001 \\
\text { (hypoglycemia) } \\
<0.001 \\
\text { (hyperglycemia) }\end{array}$ \\
\hline Bilotta et $\mathrm{al}^{34}$ & 2008 & $\mathrm{RCT}$ & NCC & $\begin{array}{l}\text { IIT }(B G C<220 \mathrm{mg} / \mathrm{dL}) \text { vs. CIT } \\
\text { (BGC } 80-120 \mathrm{mg} / \mathrm{dL}) \text { in terms } \\
\text { of hypoglycemia incidence, } \\
\text { ICU-LOS, infection and mor- } \\
\text { tality rate }\end{array}$ & $\begin{array}{l}\text { IIT group had higher hy- } \\
\text { poglycemia incidence, } \\
\text { shorter ICU-LOS, while } \\
\text { infection and mortality } \\
\text { incidence were similar } \\
\text { among the groups }\end{array}$ & $\begin{array}{l}<0.0001 \\
\text { (hypoglycemia) } \\
<0.05 \\
\text { (ICU-LOS) } \\
>0.05 \\
\text { (infection/ } \\
\text { mortality) }\end{array}$ \\
\hline van lersel et $\mathrm{al}^{35}$ & 2012 & $\begin{array}{l}\text { Retro- } \\
\text { spec- } \\
\text { tive } \\
\text { study }\end{array}$ & NCC & $\begin{array}{l}\text { To identify risk factor for } \\
\text { hypoglycemia incidence }\end{array}$ & $\begin{array}{l}\text { The reduction in nu- } \\
\text { trition calories supply } \\
\text { and/or gastric residual } \\
\text { without insulin dose } \\
\text { reduction }\end{array}$ & $<0.04$ \\
\hline Bilotta and Rosa ${ }^{5}$ & 2012 & Editorial & $\mathrm{ICU} / \mathrm{NCC}$ & $\begin{array}{l}\text { Management of BGC in ICU/ } \\
\text { NCC patients }\end{array}$ & $\begin{array}{l}\text { "Advanced" BGC target } \\
\text { range: } 129-145 \mathrm{mg} / \mathrm{dL}\end{array}$ & - \\
\hline Bilotta et $a^{36}$ & 2015 & $\mathrm{RCT}$ & $\mathrm{ICU}$ & $\begin{array}{l}\text { Comparison of pharmaco- } \\
\text { dynamic of Humulin insulin } \\
\text { (regular) and Humalog insulin } \\
\text { (short acting) in patients } \\
\text { receiving IIT }\end{array}$ & $\begin{array}{l}\text { Humalog insulin had } \\
\text { less profound carryover } \\
\text { effect and shorter dura- } \\
\text { tion of carryover }\end{array}$ & $<0.001$ \\
\hline
\end{tabular}

Abbreviations: BGC, blood glucose concentration; CIT, conventional insulin therapy; ICU, intensive care unit; IIT, intensive insulin therapy; LOS, length of stay; NCC, neurocritical care; RCT, randomized controlled trial.

approach to maintain BGC $<215 \mathrm{mg} / \mathrm{dL} .^{3}$ The IIT group had shorter ICU-LOS and infection rate and higher hypoglycemia incidence (BGC $<50 \mathrm{mg} / \mathrm{dL}$ ), whereas the 6-month GCS score and mortality were similar. Of note, risk factors for mild hypoglycemia (BGC $<80 \mathrm{mg} / \mathrm{dL}$ ) in NCC patients who received IIT were reviewed in a retrospective case-control study that included 786 patients with nervous system disorders. ${ }^{35}$ The results from this study demonstrate that to reduce the nutrition calories supply without a simultaneous insulin dose reduction as an hyperglycemic event in the previous 24 hours or the presence of gastric residual in the previous 6 hours without insulin dose reduction is associated with an increase in the incidence of hypoglycemia.
In NCC patients, insulin infusion should be started when BGC $\geq 180 \mathrm{mg} / \mathrm{dL}$ and should be stopped when BGC $\leq 140$ $\mathrm{mg} / \mathrm{dL}$. ${ }^{1}$ Some studies recommend IIT to manage BGC in NCC patients. ${ }^{1,53}$ In these cases, a different approach should be applied to prevent iatrogenic-induced hypoglycemia. Here are some tips: subcutaneous and intravenous injecting insulin bolus and infusing high glucose concentration solution should be avoided; continuous parenteral/enteral nutrition (PN and EN) and (near) continuous glucose monitoring should be used to maintain BGC in the optimal target range and to reduce BGC variability; shorter acting insulin formulation should be used as it leads to better outcomes compared with regular insulin formulation because of the quicker on 
Table 4 Nutrition (enteral vs. parenteral)

\begin{tabular}{|c|c|c|c|c|c|c|}
\hline Authors & $\begin{array}{l}\text { Year of } \\
\text { publication }\end{array}$ & $\begin{array}{l}\text { Type of } \\
\text { study }\end{array}$ & $\begin{array}{l}\text { ICU/NCC } \\
\text { patients }\end{array}$ & $\begin{array}{l}\text { Objective of } \\
\text { the study }\end{array}$ & Outcome(s) & $p$-Value \\
\hline Desai et $\mathrm{al}^{37}$ & 2014 & Review & ICU & $\begin{array}{l}\text { Comparison of } \\
\text { EN and PN }\end{array}$ & Use of EN whenever possible & - \\
\hline $\begin{array}{l}\text { Bilotta and } \\
\text { Rosa }^{1}\end{array}$ & 2010 & Review & ICU/NCC & $\begin{array}{l}\text { Management } \\
\text { of BGC using IIT }\end{array}$ & $\begin{array}{l}\text { Continuous EN/PN when IIT is } \\
\text { instituted }\end{array}$ & - \\
\hline Tripathy ${ }^{38}$ & 2018 & Review & ICU & $\begin{array}{l}\text { Complications } \\
\text { associated with } \\
\text { EN or PN }\end{array}$ & $\begin{array}{l}\text { EN and PN are associated with } \\
\text { different complications }\end{array}$ & - \\
\hline $\begin{array}{l}\text { Gramlich } \\
\text { et al }\end{array}$ & 2004 & Review & ICU & $\begin{array}{l}\text { Comparison of } \\
\text { EN and PN }\end{array}$ & $\begin{array}{l}\text { EN caused less infectious com- } \\
\text { plications and PN was associated } \\
\text { with higher incidence of hyper- } \\
\text { glycemia. There was no differ- } \\
\text { ence in mortality rate or ICU-LOS }\end{array}$ & $\begin{array}{l}0.004 \text { (infectious } \\
\text { complications) } \\
<0.04 \\
\text { (hyperglycemia } \\
\text { incidence) } \\
0.7 \text { (mortality rate) } \\
0.6 \text { (ICU-LOS) }\end{array}$ \\
\hline Härtl et al ${ }^{40}$ & 2008 & $\begin{array}{l}\text { Pro- } \\
\text { spec- } \\
\text { tive } \\
\text { study }\end{array}$ & NCC & $\begin{array}{l}\text { Effect of timing } \\
\text { and quantity } \\
\text { of nutrition on } \\
\text { death within } \\
\text { the first } 2 \\
\text { weeks of injury }\end{array}$ & $\begin{array}{l}\text { Patients who were not fed } \\
\text { within } 5 \text { and } 7 \mathrm{~d} \text { after TBI had } \\
\text { a two- and fourfold increase of } \\
\text { mortality respectively and every } \\
10-\mathrm{kcal} / \mathrm{kg} \text { decrease in caloric } \\
\text { intake was associated with a } \\
30-40 \% \text { increase in mortality }\end{array}$ & $<0.04$ \\
\hline Carney et al ${ }^{41}$ & 2017 & $\begin{array}{l}\text { Guide- } \\
\text { lines }\end{array}$ & NCC & $\begin{array}{l}\text { Management } \\
\text { of severe TBI } \\
\text { patients }\end{array}$ & $\begin{array}{l}\text { Reduced mortality if an appropri- } \\
\text { ate nutrition approach is started } \\
\text { at least by the } 5 \text { th day and at } \\
\text { most by the } 7 \text { th day post-injury. }\end{array}$ & - \\
\hline
\end{tabular}

Abbreviations: EN, enteral nutrition; ICU, intensive care unit; IIT, intensive insulin therapy; LOS, length of stay; NCC, neurocritical care; PN, parenteral nutrition; TBI, traumatic brain injury.

and offset time; and more dilute insulin preparations (50 UI in $500 \mathrm{~mL}$ instead of $50 \mathrm{UI}$ in $50 \mathrm{~mL}$ ) should be used.

To conclude, the actual state-of-the-art evidence in literature supports the use of IIT in order to maintain BGC $<146 \mathrm{mg} / \mathrm{dL}$. We recommend maintaining BGC between 90 and $140 \mathrm{mg} / \mathrm{dL}$ using the right approach, in order to reduce incidence of iatrogenic-induced hypoglycemia.

\section{Nutrition (Enteral versus Parenteral)}

In general ICU patients, guidelines recommend the use of EN whenever possible, while EN and PN are both associated with complications. ${ }^{1,37-39}$ Despite there are no conclusive data that demonstrate a PN superiority as compared with EN, available guidelines in general ICU patients recommend the preferential use of EN, whenever possible. ${ }^{37}$ In NCC patients, the priority is to warrant an adequate nutrition supply in a timely manner; therefore, EN/PN should be started when needed, with a particular approach of continuous EN/PN if IIT is instituted. ${ }^{1}$ A narrative review reported that EN was associated with fewer infections, greater feasibility, and lower costs. ${ }^{38}$ Both EN and $\mathrm{PN}$ are associated with different complications that the caregiver must be vigilant for: (enteral) insertion problems, accidental removal, ulceration, tissue necrosis along the pathway of the tube, nausea, bloating, diarrhea, aspiration, gastric infection, etc.; (parenteral) insertion of central venous access, pneumothorax, vascular/neural injury, arrhythmias, venous thrombosis, sepsis at site of central venous catheter, etc. ${ }^{38}$ Furthermore, a systematic review of RCTs reported that
PN was associated with higher incidence of hyperglycemia, while mortality, days on a ventilator, and ICU-LOS were similar among patients receiving EN or PN..$^{39}$ A prospective study enrolling 797 patients with severe TBI showed that patients who were not fed within 5 and 7 days after TBI had a twoand fourfold increase in mortality, respectively, and every $10-\mathrm{kcal} / \mathrm{kg}$ decrease in caloric intake was associated with a 30 to $40 \%$ increase in mortality. ${ }^{40}$ To conclude, TBI guidelines delivered by Brain Trauma Foundation suggest an appropriate nutrition approach at least by the 5th day and at most by the 7th day post-injury in severe TBI patients to decrease mortality with a level IIA evidence indication. ${ }^{41}$

\section{Conclusion}

In this narrative review, we report evidence related to the predictive value of BGC abnormalities (hyperglycemia, hypoglycemia, and high BGC variability) and optimal management of insulin infusion and nutrition supply in patients admitted to general ICU and to NCC with ABI. Several and consistent studies demonstrate that BGC values at admission and during ICU/NCC stay have a strong predictive value on the clinical course and short- and long-term outcomes. ${ }^{8-20}$ In NCC, evidence on optimal BGC target range and on the use of IIT has evolved over the course of past two decades and current information supports to maintain BGC values $<146 \mathrm{mg} / \mathrm{dL}$ with IIT. At the same time, the importance of adequate and timely delivered nutrition, either through PN 
or EN supply, is now confirmed, and to establish early and appropriate nutrition in patients with ABI caused by TBI has now been included among the suggested approaches in the guideline delivered by Brain Trauma Foundation with a level IIA evidence indication. ${ }^{41}$

\section{Future Perspective}

NCC patients present some unique features, and within patients with $A B I$ there are some differences between some of the subgroups (TBI, AIS, SAH, and ICH). In patients with ABI admitted to NCC, a careful BGC management is a priority. Available clinical evidence now supports the use of IIT in NCC patients. In this subset, the target BGC should be kept between 90 and $140 \mathrm{mg} / \mathrm{dL}$ to reduce the incidence of iatrogenic-induced hypoglycemia. This recommendation is a result of a critical study of the manuscripts retrieved and our experience in our own department. Of great importance is to run IIT only when an effective nutrition supplementation is established and to stop insulin infusion when BGC is lowering and reaches values $<140 \mathrm{mg} / \mathrm{dL}$ to prevent iatrogenic-induced hypoglycemic episodes. Future studies should clarify the optimal timing and nutrition supply necessary to manipulate BGC in NCC patients. The development of "closed-loop systems" that regulate the calories supply and insulin infusion titrated by a "real-time" continuous BGC monitor might contribute to further optimize clinical management.

\section{Funding}

This review was accomplished with departmental funds.

\section{Conflict of Interest}

None declared.

\section{References}

1 Bilotta F, Rosa G. Glucose management in the neurosurgical patient: are we yet any closer? Curr Opin Anaesthesiol 2010;23(5):539-543

2 Amaral AI. Effects of hypoglycaemia on neuronal metabolism in the adult brain: role of alternative substrates to glucose. J Inherit Metab Dis 2013;36(4):621-634

3 Bilotta F, Giovannini F, Caramia R, Rosa G. Glycemia management in neurocritical care patients: a review. J Neurosurg Anesthesiol 2009;21(1):2-9

4 Jauch-Chara K, Oltmanns KM. Glycemic control after brain injury: boon and bane for the brain. Neuroscience 2014;283:202-209

5 Bilotta F, Rosa G. Glycemia management in critical care patients. World J Diabetes 2012;3(7):130-134

6 Walia S, Sutcliffe AJ. The relationship between blood glucose, mean arterial pressure and outcome after severe head injury: an observational study. Injury 2002;33(4):339-344

7 Liu-DeRyke X, Collingridge DS, Orme J, Roller D, Zurasky J, Rhoney DH. Clinical impact of early hyperglycemia during acute phase of traumatic brain injury. Neurocrit Care 2009;11(2):151-157

8 Melo JR, Di Rocco F, Blanot S, et al. Acute hyperglycemia is a reliable outcome predictor in children with severe traumatic brain injury. Acta Neurochir (Wien) 2010;152(9):1559-1565

9 Bhattacharjee S, Layek A, Maitra S, Sen S, Pal S, Gozi NK. Perioperative glycemic status of adult traumatic brain injury patients undergoing craniotomy: a prospective observational study. J Neurosurg Anesthesiol 2014;26(4):313-319

10 Bosarge PL, Shoultz TH, Griffin RL, Kerby JD. Stress-induced hyperglycemia is associated with higher mortality in severe traumatic brain injury. J Trauma Acute Care Surg 2015;79(2):289-294

11 Rau CS, Wu SC, Chen YC, et al. Stress-induced hyperglycemia, but not diabetic hyperglycemia, is associated with higher mortality in patients with isolated moderate and severe traumatic brain injury: analysis of a propensity score-matched population. Int J Environ Res Public Health 2017;14(11):E1340

12 Salehpour F, Bazzazi AM, Aghazadeh J, et al. Can serum glucose level in early admission predict outcome in patients with severe head trauma? World Neurosurg 2016;87:132-135

13 Lee SH, Kim BJ, Bae HJ, et al. Effects of glucose level on early and long-term mortality after intracerebral haemorrhage: the Acute Brain Bleeding Analysis Study. Diabetologia 2010;53(3):429-434

14 Wu YT, Li TY, Lu SC, et al. Hyperglycemia as a predictor of poor outcome at discharge in patients with acute spontaneous cerebellar hemorrhage. Cerebellum 2012;11(2):543-548

15 Appelboom G, Piazza MA, Hwang BY, et al. Severity of intraventricular extension correlates with level of admission glucose after intracerebral hemorrhage. Stroke 2011;42(7):1883-1888

16 Sun S, Pan Y, Zhao X, et al. Prognostic value of admission blood glucose in diabetic and non-diabetic patients with intracerebral hemorrhage. Sci Rep 2016;6:32342

17 Kim Y, Han MH, Kim CH, Kim JM, Cheong JH, Ryu JI. Increased short-term mortality in patients with spontaneous intracerebral haemorrhage and its association with admission glucose levels and leucocytosis. World Neurosurg 2017;98:503-511

18 Elkon B, Cambrin JR, Hirshberg E, Bratton SL. Hyperglycemia: an independent risk factor for poor outcome in children with traumatic brain injury. Pediatr Crit Care Med 2014;15(7):623-631

19 Bian L, Liu L, Wang C, et al. Hyperglycemia within day 14 of aneurysmal subarachnoid hemorrhage predicts 1-year mortality. Clin Neurol Neurosurg 2013;115(7):959-964

20 Koga M, Yamagami H, Okuda S, et al; SAMURAI Study Investigators. Blood glucose levels during the initial $72 \mathrm{~h}$ and 3-month functional outcomes in acute intracerebral hemorrhage: the SAMURAI-ICH study. J Neurol Sci 2015;350(1-2):75-78

21 Sugiura Y, Yamagami H, Sakai N, Yoshimura S; Committee of Recovery by Endovascular Salvage for Cerebral Ultra-acute Embolism (RESCUE)-Japan Study Group. Predictors of symptomatic intracranial hemorrhage after endovascular therapy in acute ischemic stroke with large vessel occlusion. J Stroke Cerebrovasc Dis 2017;26(4):766-771

22 Egi M, Bellomo R, Stachowski E, et al. Hypoglycemia and outcome in critically ill patients. Mayo Clin Proc 2010;85(3):217-224

23 Krinsley J, Schultz MJ, Spronk PE, et al. Mild hypoglycemia is strongly associated with increased intensive care unit length of stay. Ann Intensive Care 2011;1:49

24 Naidech AM, Levasseur K, Liebling S, et al. Moderate Hypoglycemia is associated with vasospasm, cerebral infarction, and 3-month disability after subarachnoid hemorrhage. Neurocrit Care 2010;12(2):181-187

25 Graffagnino C, Gurram AR, Kolls B, Olson DM. Intensive insulin therapy in the neurocritical care setting is associated with poor clinical outcomes. Neurocrit Care 2010;13(3):307-312

26 Hermanides J, Vriesendorp TM, Bosman RJ, Zandstra DF, Hoekstra JB, Devries JH. Glucose variability is associated with intensive care unit mortality. Crit Care Med 2010;38(3):838-842

27 Matsushima K, Peng M, Velasco C, Schaefer E, Diaz-Arrastia R, Frankel H. Glucose variability negatively impacts long-term functional outcome in patients with traumatic brain injury. J Crit Care 2012;27(2):125-131 
28 Okazaki T, Hifumi T, Kawakita K, et al. Blood glucose variability: a strong independent predictor of neurological outcomes in aneurysmal subarachnoid hemorrhage. J Intensive Care Med 2018;33(3):189-195

29 van den Berghe G, Wouters P, Weekers F, et al. Intensive insulin therapy in critically ill patients. N Engl J Med 2001;345(19):1359-1367

30 Finfer S, Chittock DR, Su SY, et al; NICE-SUGAR Study Investigators. Intensive versus conventional glucose control in critically ill patients. N Engl J Med 2009;360(13):1283-1297

31 Al-Tarifi A, Abou-Shala N, Tamim HM, Rishu AH, Arabi YM. What is the optimal blood glucose target in critically ill patients? A nested cohort study. Ann Thorac Med 2011;6(4):207-211

32 Okawa M, Kunimoto F, Kanamoto M, et al. Effect of different blood glucose target levels on the incidence of hypoglycemia during insulin therapy in the intensive care unit. J Diabetes 2013;5(1):51-56

33 Siegelaar SE, Hermanides J, Oudemans-van Straaten HM, et al. Mean glucose during ICU admission is related to mortality by a U-shaped curve in surgical and medical patients: a retrospective cohort study. Crit Care 2010;14(6):R224

34 Bilotta F, Caramia R, Cernak I, et al. Intensive insulin therapy after severe traumatic brain injury: a randomized clinical trial. Neurocrit Care 2008;9(2):159-166
35 van Iersel FM, Slooter AJ, Vroegop R, et al. Risk factors for hypoglycaemia in neurocritical care patients. Intensive Care Med 2012;38(12):1999-2006

36 Bilotta F, Badenes R, Lolli S, Belda FJ, Einav S, Rosa G. Insulin infusion therapy in critical care patients: regular insulin vs short-acting insulin. A prospective, crossover, randomized, multicenter blind study. J Crit Care 2015;30(2):437.e1-437.e6

37 Desai SV, McClave SA, Rice TW. Nutrition in the ICU: an evidence-based approach. Chest 2014;145(5):1148-1157

38 Tripathy S. Nutrition in the neurocritical care unit. J Neuroanaesth Crit Care 2018;2:88-96

39 Gramlich L, Kichian K, Pinilla J, Rodych NJ, Dhaliwal R, Heyland DK. Does enteral nutrition compared to parenteral nutrition result in better outcomes in critically ill adult patients? A systematic review of the literature. Nutrition 2004;20(10):843-848

40 Härtl R, Gerber LM, Ni Q Ghajar J. Effect of early nutrition on deaths due to severe traumatic brain injury. J Neurosurg 2008;109(1):50-56

41 Carney N, Totten AM, O'Reilly C, et al. Guidelines for the management of severe traumatic brain injury. Neurosurgery 2017;80(1):6-15 